\title{
The genus Calastacus Faxon, 1893 in France with a new species from off Brittany (Crustacea, Decapoda, Axiidae)
}

\author{
Nguyen NGOC-HO \\ Muséum national d'Histoire naturelle, \\ Département Milieux et Peuplements aquatiques, \\ 57 rue Cuvier, F-75231 Paris cedex 05 (France) \\ nngoc-ho@mnhn.fr
}

KEY WORDS

Crustacea,

Decapoda, Axiidae,

Calastacus laurentae $\mathrm{n}$. sp., France, new species.
Ngoc-Ho N. 2011. - The genus Calastacus Faxon, 1893 in France with a new species from off Brittany (Crustacea, Decapoda, Axiidae). Zoosystema 33 (4): 515-521. DOI: 10.5252/ z2011n4a4.

\begin{abstract}
Calastacus laurentae n. sp. is the second species of Calastacus from France and Europe besides C. laevis de Saint Laurent, 1972. The description is based on two small specimens collected on the continental slope of the Bay of Biscay, off Brittany (France). The holotype is nearly complete while the second specimen is much damaged with a missing carapace; it is not considered a paratype. Calastacus laurentae n. sp. differs from all known Calastacus species by having a pair of large distal spines on the rostrum and spinules on lateral borders of the telson. It can be distinguished from $C$. laevis by the pereopod 1 bearing a small subdistal spine on both the upper and lower borders of the merus along with a fine longitudinal upper carina on the propodus; by contrast in C. laevis, there are one large upper spine and five large lower spines on the pereopod 1 merus and no upper carina on the propodus. Also in the new species, the terminal suture on the uropodal exopod is faint and unarmed while it is well defined and bears spinules in C. laevis.
\end{abstract}




\author{
MOTS CLÉS \\ Crustacea, \\ Decapoda, \\ Axiidae, \\ Calastacus laurentae n. sp., \\ France, \\ espèce nouvelle.
}

\begin{abstract}
RÉSUMÉ
Le genre Calastacus Faxon, 1893 en France avec une nouvelle espèce provenant du large de la Bretagne (Crustacea, Decapoda, Axiidae).

Calastacus laurentae n. sp. est la deuxième espèce de Calastacus de France et d'Europe après C. laevis de Saint Laurent, 1972. La description est fondée sur deux petits spécimens capturés dans le Golfe de Gascogne, au large de la Bretagne (France), dont le premier, l'holotype, est presque complet alors que le second est endommagé et dépourvu de carapace; il n'est pas considéré comme un paratype. Calastacus laurentae n. sp. diffère des autres espèces de Calastacus par la présence d'une paire de fortes épines latérales distales sur le rostre et des spinules aux bords latéraux du telson. Elle se distingue de C. laevis de Saint Laurent, 1972 par le péréiopode 1 muni d'une petite épine subdistale à la fois aux bords supérieur et inférieur du mérus et d'une fine carène longitudinale supérieure au propode; par contre chez $C$. laevis, le péréiopode 1 a une forte épine au bord supérieur et cinq fortes épines au bord inférieur du mérus alors que la carène supérieure est absente au propode. D'autre part, la suture terminale de l'exopodite des uropodes est très faible et inerme chez la nouvelle espèce alors qu'elle est distincte et garnie de spinules chez C. laevis.
\end{abstract}

\section{INTRODUCTION}

Despite the long history of biodiversity exploration in European seas, new species of benthic macroinvertebrates continue to be discovered off the French coasts (e.g., Salvini-Plawen 2008; Aguirrezabalaga \& Gil 2009; Di Geronimo 2009). The new species of Calastacus Faxon, 1893 presented in this work was identified by Michèle de Saint Laurent and reported by Ngoc-Ho (2003: 440).

WoRMS (World Register of Marine Species) lists 11 species for the genus but several axiids that have been described in the genus or subgenus Calastacus are now placed in other genera.

The genus Calastacus Faxon was most recently diagnosed and discussed by Poore \& Collins (2009: 247). Seven species were listed: C. stilirostris Faxon, 1893 (type species) from off Mexico, C. laevis de Saint Laurent, 1972 from the Bay of Biscay, north of Spain, C. colpos Kensley, 1996 and C. mexicanus Kensley, 1996 from the Gulf of Mexico, C. crosnieri Kensley \& Chan, 1998 as well as C. formosus Komai, Lin \& Chan, 2010 from Taiwan, western Pacific, and C. inflatus Komai \& Lin \& Chan, 2009 from Pratas Island, southern China sea. A species was added: C. myalup Poore \& Collins, 2009 from western Australia, but three species were missing from the list: C. angulatus Coelho, 1973, C. spinosus Coelho, 1973, C. vicina Coelho \& Ramos-Porto, 1985, all briefly diagnosed from Brazil.

With C. laevis de Saint Laurent, 1972, the new taxon, $C$. laurentae $\mathrm{n}$. sp. is the second species of the genus in Europe.

The description is based on two specimens collected during a RV Thalassa expedition led by Dr Louis Cabioch (station biologique de Roscoff), in October 1973.

\section{MATERIALS AND METHOD}

The first specimen, the holotype, is almost complete while the second specimen, with similar data, is much damaged and with a missing carapace. This specimen can presumably be assigned to the same species as the holotype but as the carapace is missing, this cannot be confirmed. It is figured but not considered a paratype.

The material studied is deposited in the collections of the Muséum national d'Histoire naturelle, 
Paris (MNHN). The measurements given in the description are the carapace length (cl.) and the total length (tl.).

Specimens and appendages were stained with a weak solution of chlorazol black. The anterior part of the carapace, the telson and uropods are figured in dorsal view, the whole specimen and appendages are figured in lateral view.

\section{SYSTEMATICS}

Family AXIIDAE Huxley, 1879

Genus Calastacus Faxon, 1893

\section{Calastacus laurentae n. sp.}

(Figs 1;2)

TYPe MATERIAL. - Holotype: Continental slope south of La Chapelle Bank, France, Thalassa, 1973, stn Z400, $47^{\circ} 33,4^{\prime} \mathrm{N}, 07^{\circ} 19^{\prime} \mathrm{W}, 1175 \mathrm{~m}, 22 . X .1973,13 \mathrm{~h}-15.35 \mathrm{~h}$, muddy sand and rocks: hermaphrodite, lc. $8 \mathrm{~mm}$, lt. $18 \mathrm{~mm}$ (MNHN Th 346), right pereopod 4, right uropods, left pereopods 2-4 missing.

OTHER MATERIAL EXAMINED. - Continental slope south of Little Sole [Petite Sole] Bank, off Brittany, France, Thalassa 1973, stn Z412, 48 ${ }^{\circ} 1,6^{\prime} \mathrm{N}, 08^{\circ} 26^{\prime} \mathrm{W}, 1250 \mathrm{~m}$, 24.X.1973, 1.15h-3.05h, clayey mud; broken specimen without carapace, abdomen (length $14 \mathrm{~mm}$ ) present along with right pereopods 1, 2, 4 and a few dissected mouth appendages (MNHN Th 349).

Etymology. - The species is named for Michèle de Saint Laurent who had recognized it as a new species of Calastacus.

\section{DESCRIPTION}

Carapace (Fig. 1A) slightly shorter than abdomen, laterally compressed, upper border rounded. Cervical groove weakly defined dorsally, very faint laterally. Rostrum (Fig. 1B) as long as antennular peduncle, with pointed tip, slightly depressed on upper side, bearing two pairs of large spines, one at base, the other distally on either side of rostral tip. Fine median gastric carina extending approximately from base of rostrum to halfway to cervical groove; two short carinae on either side and linked to it by two oblique branches.

Abdomen (Fig. 1G) 1.2 times longer than carapace, pleura 1 pointed ventrally, those of segments
3, 4, and 5 with lower-distal spinule in holotype (Fig. 1A) as in specimen MNHN Th 349.

Telson approximately 1.5 times as long as wide in specimen MNHN Th 349 (Fig. 1G), 1.70 times as long as wide in holotype (Fig. 1C); lateral borders with spinules similarly arranged but more numerous in holotype and a pair of lateral distal spines in both specimens; posterior border rounded.

Eyes (Fig. 1B) globulous, hardly mobile.

Second article of antennal peduncle (Fig. 1A, B) terminating distally in a point, with a lower distal spine; scaphocerite long, styliform, nearly reaching distal third of penultimate article of peduncle.

Maxilliped 1 (Fig. 2A) with large epipod.

Maxilliped 2 (Fig. 2B) with exopod, epipod partly broken.

Maxilliped 3 (Fig. 2C, D) ischium of endopod with crista dentata bearing 11 teeth; merus with two lateral distal spines on lower border; exopod broken.

Pereopods 1 (Fig. 1A, D) subequal in holotype, only right pereopod 1 present in specimen MNHN Th 349. Merus with small upper distal spinule and a spine at distal third of lower border, latter being more distinct in holotype; propodus with fine longitudinal upper carina terminating in distal spinule in holotype, spinule absent in specimen MNHN Th 349; fixed finger nearly as long or slightly longer than palm with curved tip, cutting edge bearing three or four conical teeth; dactylus with curved tip and large rounded proximal tooth on cutting edge.

Pereopod 2 (Fig. 1E) much smaller than pereopod 1, unarmed, fixed finger and dactylus with small pectiniform setae on cutting edge.

Pereopods 3, 4, 5 (Figs 1A; 2F) all unarmed, dactylus stout and short in pereopod 3, longer and slender in pereopods 4 and 5 .

Branchial formula of $C$. laevis was presented by de Saint Laurent (1972: 350). In the present species, except for the gills of maxilliped 1 (Fig. 2A) and pereopod 1 (Fig. 1D) those of other appendages were not examined.

Female and male gonopores open on coxae of pereopods 3 and 5 . 


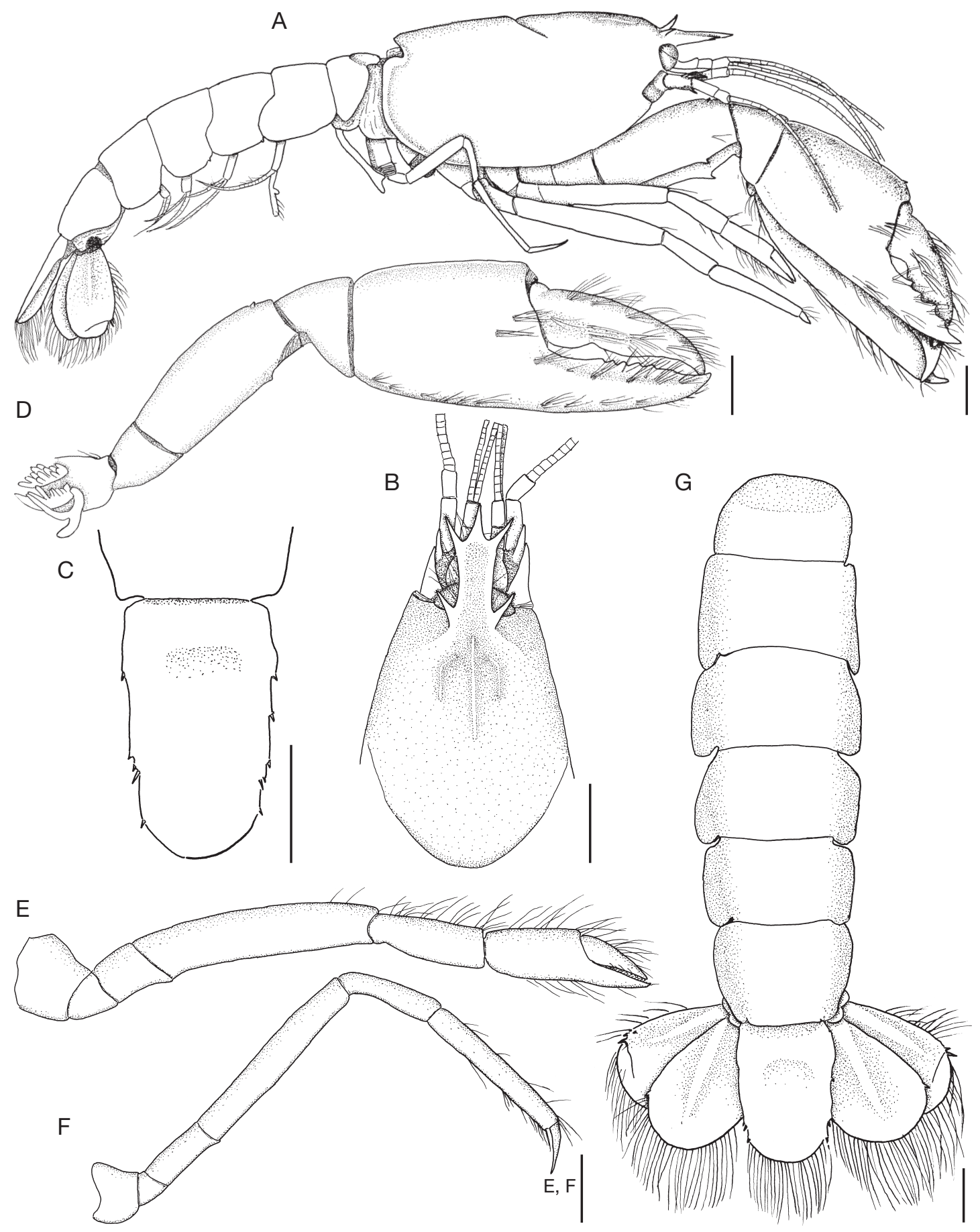

FIG. 1. - Calastacus laurentae n. sp.: A, lateral view; B, anterior part of carapace; C, telson; D, pereopod 1; E, pereopod 2; F, pereopod 4; G, abdomen, telson and uropods. A-C, holotype (MNHN Th 346); D-G, specimen MNHN Th 349. Scale bars: 1 mm. 
A

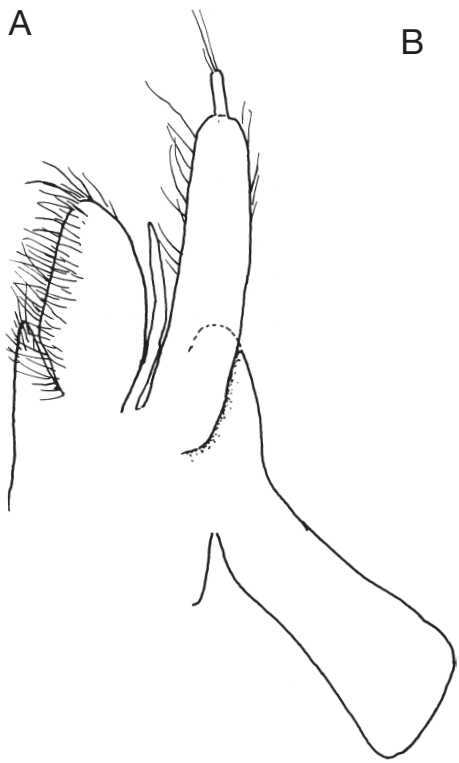

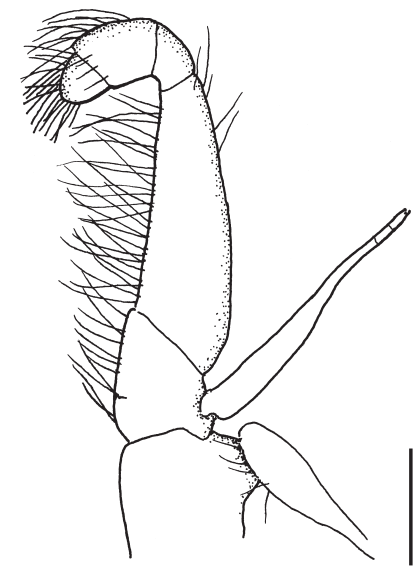

C

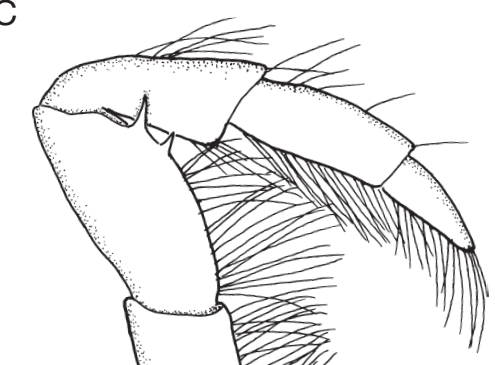

$\mathrm{E}$

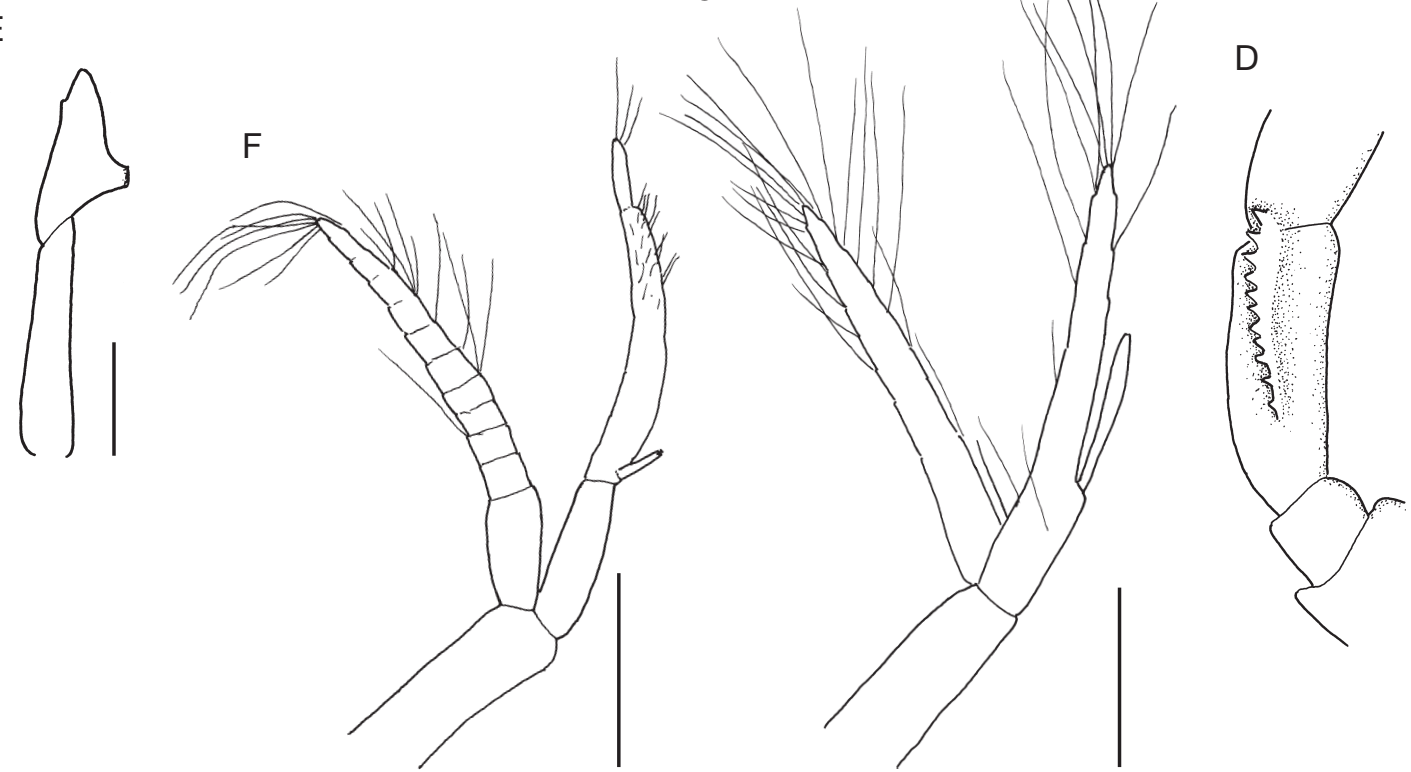

FIG. 2. - Calastacus laurentae n. sp.: A-C, maxilliped 1, 2 and 3; D, ischium of maxilliped 3, mesial view; E, pleopod 1; F, G, pleopod 2 and 3. A-D, F, G, specimen MNHN Th 349; E, holotype (MNHN Th 346); Scale bars: $1 \mathrm{~mm}$.

Pleopod 1 (Fig. 2E) two-articulated, proximal article long and slender, distal article larger with a small internal projection, no visible appendix interna.

Pleopod 2 (Fig. 2F) biramous, exopod slender, endopod divided into a basal article and a appendix masculina of two faintly separated articles carrying tiny setae; short appendix interna fused to base of appendix masculina.

Pleopods 3-5 (Fig. 2G) biramous, exopod and endopod slender with long appendix interna. 
Uropods (Fig. 1G) about as long as telson, posterior border rounded, endopod with one external distal spine, exopod with two external distal spines; very faint and unarmed suture on distal part of exopod.

\section{DISCUSSION}

The new taxon differs essentially from known Calastacus species by having: 1) a pair of large lateral distal spines on the rostrum besides the supraoculars; and 2) spinules on lateral borders of the telson.

Calastacus laurentae n. sp. resembles C. laevis, the other European Calastacus species (de Saint Laurent 1972: 352, fig. 9) and also C. stilirostris, type species (Faxon 1895: fig. 1e), by the appendix masculina of pleopod 2 bearing few setae while setae are dense on the appendix masculina of many other species, e.g., C. crosnieri (Kensley \& Chan 1998: fig. 5F), C. colpos (Kensley 1996: fig. 2F), C. mexicanus (Kensley 1996: fig. 4E), C. inflatus (Komai et al. 2010: fig. 7G). Unlike the other species mentioned above with the pleopod 2 bearing an appendix masculina of two diffentiated articles, in both European species of Calastacus the two articles are faintly separated ("incomplètement divisés”) in C. laevis (de Saint Laurent 1972: 350, fig. 9) as in C. laurentae n. sp. (Fig. 2F).

Calastacus laurentae n. sp. can be differentiated from $C$. laevis by: 1) the pereopod 1 bearing a small subdistal spine on the upper and lower border of merus whilst one upper subdistal spine and five lower spines are present on the merus in C. laevis; 2 ) the pereopod 1 propodus bearing a fine longitudinal upper carina, such carina is absent in C. laevis; and 3) the distal suture on uropodal exopod is faint and unarmed while it is well defined and armed with spinules in C. laevis.

It can be noted that the holotype of $C$. laurentae n. $\mathrm{sp} .(\mathrm{cl} .8 \mathrm{~mm})$ is probably a young specimen that is smaller than the holotype of most known species, except for C. formosus (cl.7.1 mm), and especially smaller than the holotype of $C$. laevis (cl. $14.5 \mathrm{~mm}$ ).

On the other hand, with a single lower spine on the pereopod 1 merus and an unarmed distal suture on the uropod exopod, this species is similar to C. inflatus of the southern China sea.

\section{Acknowledgements}

The author wishes to thank Louis Cabioch (station biologique de Roscoff) who, in the late 1960s-early 1970 s, led surveys of the benthic fauna of the continental slope of the Iberian Peninsula and Bay of Biscay, the last of which sampled the new species described here; Gary Poore and Pierre Noël who have read the manuscript and Darryl Felder for his comments as reviewer.

\section{REFERENCES}

Aguirrezabalaga F. \& Gil J. 2009. - Paraonidae (Polychaeta) from the Capbreton Canyon (Bay of Biscay, NE Atlantic) with the description of eight new species. Scientia Marina 73 (4): 631-666.

Coelho P. A. 1973. - Descriçao preliminar de Calastacus angulatus, n. sp., et de C. spinosus n. sp. , do Norte do Brasil (Crust., Decapoda, Axiidae). Ciência e Cultura, Supplemento, 25: 344-345.

Coelho P. A. \& Ramos-Porto M. 1985. - Sinopse dos crustaceos decápodos brasilieros (famílias Scyllaridae, Palinuridae, Nephropidae, Parastacidae e Axiidae). Anais da Universidade Federal Rural de Pernambuko, 8/10: 47-88 (dated 1983/85, published 1985).

Di Geronimo R. 2009. - A new species of Gruvelialepas Newman, 1980 (Crustacea, Cirripedia) from the northern Atlantic and remarks on living and fossil closely-related genera. Zoosystema 31 (1): 63-70.

FAXON W. 1895. - Reports on an exploration off the west coast of Mexico, Central and South America, and off the Galapagos Islands, in charge of Alexander Agassiz, by the U.S. Fish Commission Steamer "Albatross" during 1891, Lieut-Commander Z.I. Tanner U.S.N. commanding. XV. The stalk-eyed Crustacea. Memoirs of the Museum of Comparative Zoology at Harvard College 18: 1-292.

KENSLEY B. 1996. - New species of Calocarididae from the Caribbean Sea and Gulf of Mexico (Crustacea: Decapoda: Thalassinidea). Bulletin of Marine Science 59 (1): 158-168.

Kensley B. \& Chan T.-Y. 1998. - Three new species of thalassinidean shrimps (Crustacea, Axiidae and Calocarididae) from Taiwan. Zoosystema 20 (2): 255-264.

Komai T., Lin F.-J. \& Chan T. Y. 2009. —A new mudshrimp species of Calastacus (Crustacea: Decapoda: Thalassinidea) from the South China Sea. Zootaxa 2008: 24-30.

Komai T., Lin F.-J. \& Chan T. Y. 2010. - Five new species of Axiidae (Crustacea: Decapoda: Axiidea) from deep-water off Taiwan, with description of a new genus. Zootaxa 2352: 1-28. 
NGOC-Ho N. 2003. - European and Mediterranean Thalassinidea (Crustacea, Decapoda). Zoosystema 25 (3): 439-555.

Poore G. C. B. \& Collins D. J. 2009. - Australian Axiidae (Crustacea: Decapoda: Axiidea). Memoirs of Museum Victoria 66: 221-287.

Saint Laurent M. DE 1972. — Un Thalassinide nou- veau du golfe de Gascogne, Calastacus laevis sp. nov. Remarques sur le genre Calastacus Faxon (Crustacea Decapoda Axiidae). Bulletin du Muséum national d'Histoire naturelle, 3e série, Zoologie 29: 347-356.

Salvini-Plawen L. von 2008. - Contributions to West European Cavibelonia (Mollusca, Solenogastres) with two new species. Zoosystema 30 (4): 873-897.

Submitted on 3 June 2010; accepted on 23 June 2011. 